\title{
Sugarcane froghoppers in northeast Brazil
}

\section{Cigarrinhas da cana-de-açúcar no nordeste brasileiro}

\author{
Jayara Dayany da Costa Silva1,2* (D) (orcid.org/0000-0002-1495-6383) \\ Solange Maria de França ${ }^{3}$ (DD (orcid.org/0000-0001-7602-6635) \\ Diego Olympio Peixoto Lopes 4 (D) (orcid.org/0000-0001-8586-1640) \\ Leila Luci Dinardo-Miranda ${ }^{5}$ (D) (orcid.org/0000-0002-4390-5024) \\ Francisco de Alcântara Neto ${ }^{6}$ (D) (orcid.org/0000-0002-7656-6700) \\ Paulo Roberto Ramalho Silva7 (D) (orcid.org/0000-0001-5928-3226)
}

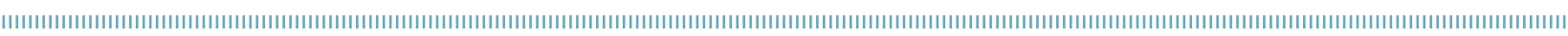

\begin{abstract}
Froghoppers (Mahanarva spp.) are pests of great economic importance for various regions of Brazil. Many species have a variation in the alar pattern, a parameter that often leads to incorrect identification. We collected froghopper adults in sugarcane fields in the municipalities of Murici and Maceió, in Alagoas, Lagoa de Itaenga and Camutanga, in Pernambuco, São Raimundo das Mangabeiras, in Maranhão, and União and Boa Hora, in the Teresina microregion in Piauí. The froghoppers were assembled and identified and are representatives of three species: M. spectabilis, $M$. fimbriolata, and $M$. posticata. This is the first record of $M$. spectabilis attacking sugarcane fields in the states of Piauí and Maranhão, Brazil. We found the species M. posticata and M. fimbriolata in the sugarcane fields of Alagoas and only M. posticata in Pernambuco.
\end{abstract}

KEYWORDS: pasture froghopper; root froghopper; occurrence; identification.
RESUMO: As cigarrinhas (Mahanarva spp.) são pragas de grande importância econômica em várias regiōes do país. Muitas espécies têm variação no padrão alar, parâmetro que leva muitas vezes à identificação de forma incorreta. Adultos de cigarrinhas foram coletados em canaviais nos municípios de Murici e Maceió em Alagoas, Lagoa de Itaenga e Camutanga em Pernambuco, São Raimundo das Mangabeiras em Maranhão e União e Boa Hora, microrregião de Teresina em Piauí, e foram montados e identificados. As cigarrinhas coletadas são representantes de três espécies $M$. spectabilis, $M$. fimbriolata e $M$. posticata, sendo este o primeiro registro da espécie M. spectabilis atacando canaviais nos estados do Piauí e Maranhão. Em canaviais de Alagoas, foram encontradas as espécies M. posticata e $M$. fimbriolata e, em Pernambuco, apenas $M$. posticata.

PALAVRAS-CHAVE: cigarrinha-das-pastagens; cigarrinha-das-raízes; ocorrência; identificação.

\footnotetext{
'Universidade Federal do Piauí - Teresina (PI), Brazil

${ }^{2}$ Instituto Federal de Educação, Ciência e Tecnologia do Piauí - Oeiras (PI), Brazil

${ }^{3}$ Departamento de Fitotecnia, Universidade Federal do Piauí - Teresina (PI), Brazil

“Universidade Estadual Paulista “Júlio de Mesquita Filho" - Jaboticabal (SP), Brazil

${ }^{5}$ Instituto Agronômico, Centro de Cana-de-Açúcar - Ribeirão Preto (SP), Brazil

${ }^{6}$ Departamento de Fitotecnia, Universidade Federal do Piauí - Teresina (PI), Brazil

${ }^{7}$ Laboratório de Fitossanidade, Departamento de Fitotecnia, Centro de Ciências Agrárias, Universidade Federal do Piauí - Teresina (PI), Brazil

*Corresponding author: jayara.silva@ifpi.edu.br

Received on: $11 / 04 / 2018$. Accepted on: 07/05/2020
} 
Froghoppers of the genus Mahanarva (Hemiptera: Cercopidae) are considered pests that cause severe damage to several species of grasses of economic importance in Brazil and worldwide, such as Saccharum spp. (sugarcane), Pennisetum purpureum Schumacher, 1827 (elephant grass), and Brachiaria ruziziensis Germain and Evrard, 1953 (Brachiaria grass). These crops are attacked quite frequently. Estimates point to losses caused by these insects at around two million dollars a year worldwide (AUAD et al., 2007; DINARDO-MIRANDA, 2014; SOBRINHO et al., 2010).

These insects are popularly known as grasshoppers or sugarcane froghoppers. Species of this genus cause damage by feeding on plant sap. Both young and adults, when feeding, inject toxic substances into plants, which cause leaf necrosis and compromise the photosynthetic process, reducing plant growth and production. The young or nymph forms, in addition, extract large amounts of water and nutrients directly from the roots, while adults suck the sap from leaves, where they inject toxins (GARCIA et al., 2007; DINARDO-MIRANDA, 2014; RESENDE et al., 2012).

DISTANT (1909) first described the genus Mahanarva in 1909, Mahanarva indicata was the type species, whose origin is attributed to Brazil. Currently, the genus has 46 described species (PALADINI; CAVICHIOLI, 2014; ALVES; CARVALHO, 2014). In Brazil, the species Mahanarva fimbriolata (Stål 1854) and Mahanarva posticata (Stål, $1855)$ are commonly found in sugarcane, where they cause significant losses. DINARDO-MIRANDA (2014), however, states that $M$. fimbriolata is uncommon in sugarcane fields in southeastern Brazil, where another species of Mahanarva predominates, but whose identification is not yet clear. Mahanarva spectabilis (Distant, 1909) is commonly associated with pastures, where it is considered a limiting factor for their development. However, it was recorded only once attacking sugarcane fields in Goiás together with Mahanarva liturata (Le Peletier and Serville, 1825). This is thus the first record of these species in sugarcane in Brazil (PEIXOTO et al., 2009; AUAD et al., 2011; ALVES; CARVALHO, 2014).

These species of grasshoppers have similarities in body size and alar pattern. These characteristics are related to phenotypic plasticity, which often makes it difficult to correctly identify species (CASTRO et al., 2007). For this, it is necessary to differentiate them using the male genitalia. This identification technique confirms the presence of $M$. spectabilis in an area where $M$. fimbriolata was believed to be present (ALVES; CARVALHO, 2014; PAULA-MORAES et al., 2008; DINARDO-MIRANDA, 2014).

This work was carried out with the objective of identifying and recording species of froghoppers that occur in sugarcane fields in the northeastern states of Brazil.
Adult froghoppers were collected in sugarcane fields in the municipalities of Murici and Maceió, in Alagoas, Lagoa de Itaenga and Camutanga, in the Forest Zone of Pernambuco, São Raimundo das Mangabeiras, in Maranhão, and Uniâo and Boa Hora, in the Teresina microregion in Piauí. They were kept in plastic containers containing 70\% alcohol and transported to the Phytosanitary Laboratory of the Phytotechnics Department of the Agricultural Sciences Center of the Federal University of Piauí. They were then quantified, stored in falcon tubes, and sent to an expert of the Center of Sugarcane from Agronomic Institute of Campinas for species identification, which was carried out by observing the genitalia.

The collected froghoppers are representative of three species: M. spectabilis, M. fimbriolata, and M. posticata. We found that the froghoppers collected in the sugarcane fields of Piauí are M. spectabilis. In Maranhão, we found only M. spectabilis and M. fimbriolata; in Pernambuco, only $M$. posticata; and in Alagoas, M. fimbriolata and $M$. posticata (Table 1). This is, thus, the first record of the species $M$. spectabilis' attacking sugarcane fields in the states of Piauí and Maranhão.

Mahanarva spectabilis is a pest frequently associated with pastures cultivated with $P$. purpureum and B. brizantha. It is considered one of the main problems limiting the development of forage grasses. However, the recording of this species is rare. It causes damage to sugarcane. There is only one record in Brazil (AUAD et al., 2007; AUAD et al., 2009; ALVES; CARVALHO, 2014).

Many species of cercopids have variations in the alar pattern. This variation makes it possible for specimens of Mahanarva spp. to present similarities in the pattern of tegmina. Species can thus be differentiated only by the male's genitals, mainly the parameter (ALVES; CARVALHO, 2014). Mahanarva spectabilis has a great variation in the alar color pattern (Fig. 1), which is very similar to that of $M$. fimbriolata. This can cause confusion in the correct identification of the species present in the area. Thus, there is a need for identification through male genitalia analysis and not only visualizing the alar pattern: the parts of the

Table 1. Specimens of froghoppers collected in sugarcane fields in the northeast, Brazil.

\begin{tabular}{cc|}
\hline Location & Species \\
\hline Maceió - AL & M. posticata \\
\hline Murici - AL & M. fimbriolata \\
\hline Lagoa de Itaenga - PE & M. posticata \\
\hline Camutanga-PE & M. posticata \\
\hline Balsas - MA & M. spectabilis and M. fimbriolata \\
\hline Boa Hora - PI & M. spectabilis \\
\hline União - PI & M. spectabilis \\
\hline
\end{tabular}


male genitalia of $M$. spectabilis, that is, aedeagus with a sickle-shaped, curved, dorsal process at the extremity (Fig. 2) (ALVES; CARVALHO, 2014). AUAD et al. (2009) described four wing patterns in $M$. spectabilis collected from pastures in Brasília, Federal District, and Presidente Prudente, São Paulo. The color descriptions were straw-yellow with black longitudinal spots, reddish with longitudinal black spots, totally red, and totally black. Individuals of this species collected in Maranhão and Piauí showed five wing color patterns: brown (Figs. 1A and 1B), black (Fig. 1B), reddish (Fig. 1C), reddish with dark spots on the posterior wing (Fig. 1D), and straw yellow (Fig. 1E).

The species $M$. fimbriolata, $M$. posticata and $M$. spectabilis are present in sugarcane fields in northeastern Brazil. This study reported the first occurrence of $M$. spectabilis in sugarcane fields in the states of Piauí and Maranhão, Brazil.

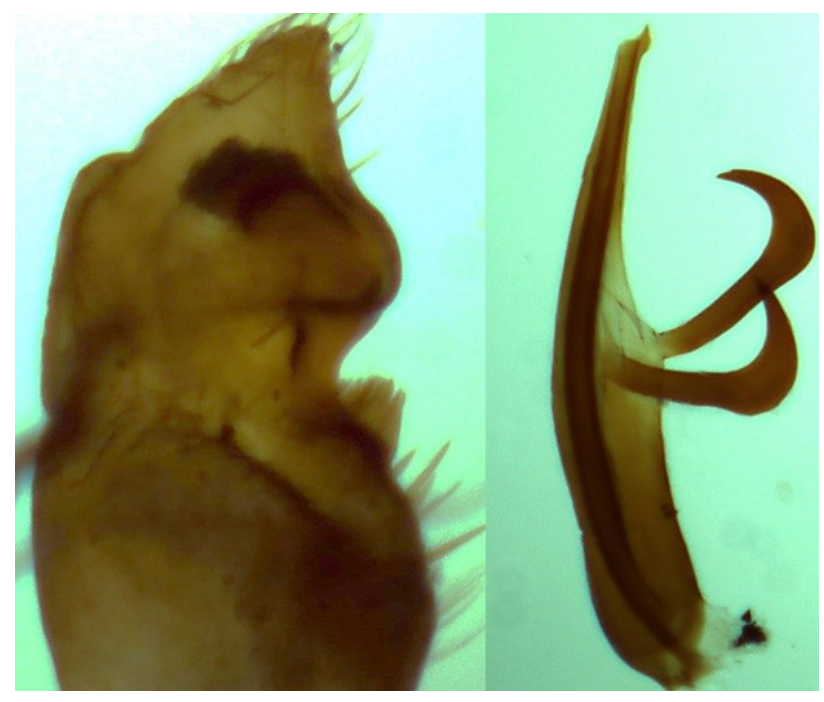

Source: DINARDO-MIRANDA (2018).

Figure 2. Male genitalia of Mahanarva spectabilis.

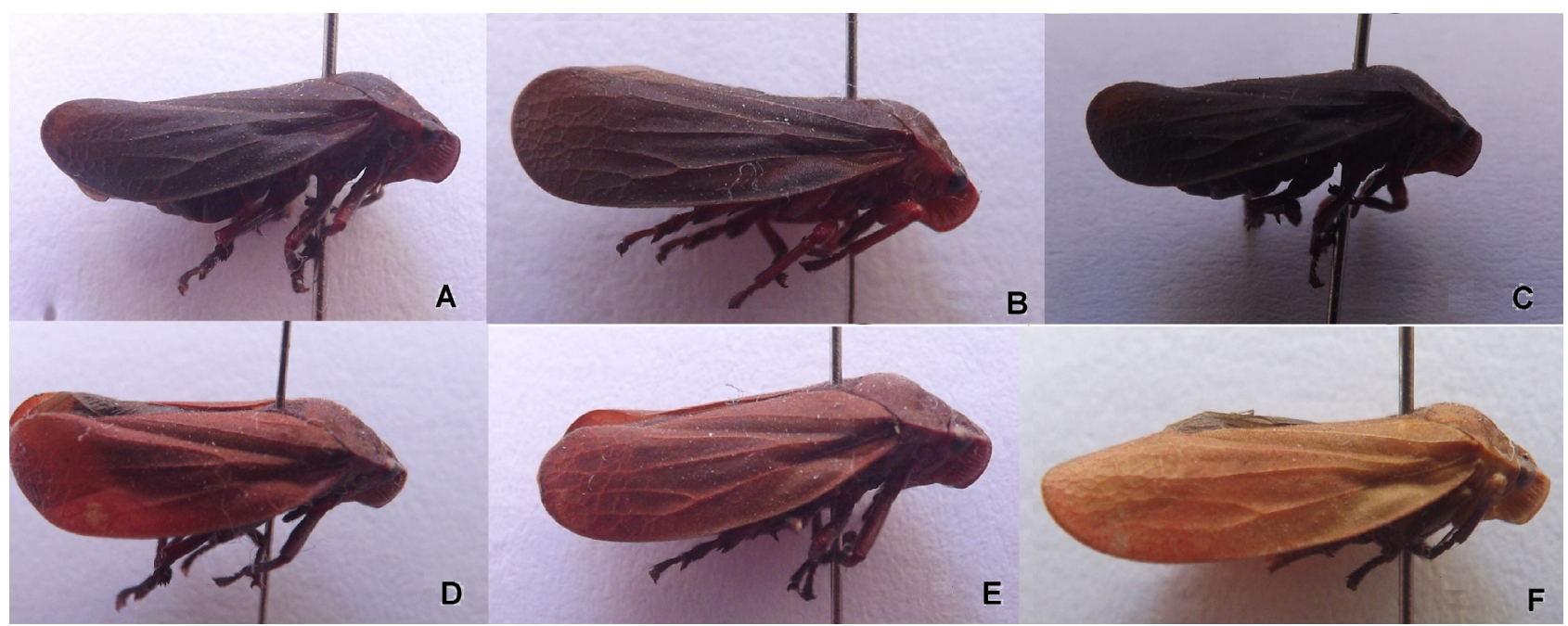

Source: SILVA (2019).

Figure 1. Alar pattern of Mahanarva spectabilis collected in sugarcane fields.

ACKNOWLEDGEMENTS: We thank the Genetic Improvement Program for Sugarcane of UFPI (PMGCA-UFPI/RIDESA) for the support logistics in the field and the material made available for this research.

FUNDING: This study was financed in part by the Coordenação de Aperfeiçoamento de Pessoal de Nível Superior - Brasil (CAPES) Finance Code 001.

CONFLICTS OF INTEREST: All authors declare that they have no conflict of interest.

ETHICAL APPROVAL: Not applicable.

AVAILABILITY OF DATA AND MATERIAL: The datasets analyzed during the current study are available from the corresponding author on reasonable request.

AUTHORS' CONTRIBUTIONS: Conceptualization and methodology: Silva, J.D.C.; França, S.M. de; Silva, P.R.R. Investigation: Silva, J.D.C.; França, S.M.; Alcântara Neto, F.; Silva, P.R.R.; Dinardo-Miranda, L.L.; Lopes, D.O.P. Writing original draft, and writing — review \& editing: Silva, J.D.C.; França, S.M.; Alcântara Neto, F.; Silva, P.R.R. 


\section{REFERENCES}

AUAD, A.M.; SIMÕES, A.D.; VANDER PEREIRA, A.; BRAGA, A.L.F.; SOBRINHO, F.S.; DA SILVA LÉDO, F.J.; PAULA-MORAES, S.V.; OLIVEIRA, S.A.; FERREIRA, R.B. Seleção de genótipos de capimelefante quanto à resistência à cigarrinha-das-pastagens. Pesquisa Agropecuária Brasileira, v.42, n.8, p.1077-1081, 2007. https:// doi.org/10.1590/S0100-204X2007000800003

AUAD, A.M.; DE CARVALHO, C.A.; DA SILVA, D.M.; DERESZ, F. Flutuação populacional de cigarrinhas-das-pastagens em braquiária e capimelefante. Pesquisa Agropecuária Brasileira, v.44, n.9, p.1205-1208, 2009. https://doi.org/10.1590/SO100-204X2009000900020

AUAD, A.M.; SIMOES, A.D.; LEITE, M.V.; DA SILVA, S.E.B.; DOS SANTOS, D.R.; MONTEIRO, P.H. Seasonal dynamics of egg diapause in Mahanarva spectabilis (Distant, 1909) (Hemiptera: Cercopidae) on elephant grass. Arquivos do Instituto Biológico, v.78, n.2, p.325-330, 2011.

ALVES, R.T.; CARVALHO, G.S. First record of the sugarcane froghoppers Mahanarva spectabilis (Distant) and Mahanarva liturata (Le Peletier \& Serville) infesting sugarcane plantations in the region of Goianésia (GO), Brazil. Arquivos do Instituto Biológico, v.81, n. 1, p.83-85, 2014. http://dx.doi.org/10.1590/S1808-16572014000100016

CASTRO, U.; CARDONA, C.; VERA-GRAZIANO, J.; MILES, J.; GARZA-GARCIA, R. Identificación morfológica y molecular de Prosapia simulans (Walker) (Hemiptera: Cercopidae), y selección y mecanismos de resistencia a este salivazo en híbridos de Brachiaria. Neotropical Entomology, v.36, n.4, p.547-554, 2007. http://dx.doi.org/10.1590/S1519-566X20070004000 12

DINARDO-MIRANDA, L.L. Nematoides e pragas da cana-de-açúcar. 1. ed. Campinas: Instituto Agronômico, 2014. 400p.

DINARDO-MIRANDA, L.L. Nematoides e pragas da cana-de-açúcar. 2. ed. Campinas: Instituto Agronômico, 2018. 444p.

DISTANT, W. L. LXV. Oriental Rhynchota Heteroptera. Annals and Magazine of Natural History, v.3, n.8, p.187-213, 1909. https:// doi.org/10.1080/00222930908692615
GARCIA, J.F.; GRISOTO, E.; BOTELHO, P.S.M.; PARRA, J.R.P.; APPEZZATO-DA-GLÓRIA, B. Feeding site of the spittlebug Mahanarva fimbriolata (Stål) (Hemiptera: Cercopidae) on sugarcane. Scientia Agricola, v.64, n.5, p.555-557, 2007. http://dx.doi. org/10.1590/SO103-90162007000500014

PALADINI, A.; CAVICHIOLI, R.R. Taxonomic notes on Mahanarva (Ipiranga) (Hemiptera, Cercopidae) with description of a new species. Zootaxa, v.3861, n.5, p.479-486, 2014. https://doi. org/10.11646/zootaxa.3861.5.5

PAULA-MORAES, S.V.; CARVALHO, G.S.; RAMOS, A.K.B.; AUD, A.M.; TAKADA, S.; BARCELLOS, A.O. Ocorrência da cigarrinha-daspastagens Mahanarva spectabilis (Distant, 1909) em gramíneas forrageiras e sua distribuição em áreas de Cerrado e na Amazônia Legal. In: REUNIÃO ANUAL DA SOCIEDADE BRASILEIRA DE ZOOTECNIA, 43., 2006, João Pessoa. Anais.,, João Pessoa: Sociedade Brasileira de Zootecnia, 2006. CD-ROM.

PEIXOTO, M.F.; BARBOSA, R.V.; FERNANDES, P.M.; AUGUSTO, R.B.S.; OLIVEIRA, R.R.C. Controle e perdas provocadas por Mahanarva fimbriolata (Stål)(Hemiptera: Cercopidae) em canade-açúcar. Global Science and Technology, v.2, n.1, p.114$122,2009$.

RESENDE, T.T.; AUAD, A.M.; FONSECA, M.D.G.; DOS SANTOS, T.H.; VIEIRA, T.M. Impact of the spittlebug Mahanarva spectabilis on signal grass. The Scientific World Journal, v.2012, p.926715, 2012. https://doi.org/10.1100/2012/926715

SILVA, J.D.C. Manejo ecológico da cigarrinha das raízes Mahanarva spectabilis (Distant, 1909) (Hemiptera: Cercopidae) em cana-deaçúcar. 2019. 96f. Thesis (Doctorate in Agronomy) - Universidade Federal do Piauí, Teresina, 2019.

SOBRINHO, F.S.; AUAD, A.M.; DA SILVA-LÉDO, F.J. Genetic variability in Brachiaria ruziziensis for resistance to spittlebugs. Crop Breeding \& Applied Biotechnology, v.10, n.1, p.83-88, 2010. https://doi.org/10.12702/1984-7033.v10n01a11 